ENTREPRENEURSHIP AND SUSTAINABILITY ISSUES

ISSN 2345-0282 (online) http://jssidoi.org/jesi/ 2020 Volume 8 Number 2 (December)

http://doi.org/10.9770/jesi.2020.8.2(53)
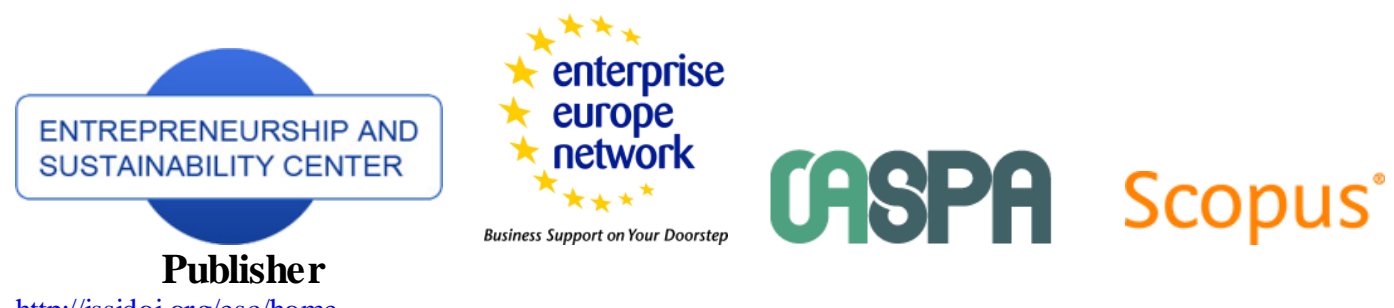

http://issidoi.org/esc/home

Business Support on Your Doorstep

I Clarivate

\title{
INFLUENCE OF ORGANISATIONAL AND INFORMATION SYSTEMS AND TECHNOLOGIES RESOURCES AND CAPABILITIES ON THE ADOPTION OF PROACTIVE ENVIRONMENTAL PRACTICES AND ENVIRONMENTAL PERFORMANCE
}

\author{
Juan Felipe Reyes-Rodríguez ${ }^{1}$, Jairo González-Bueno ${ }^{2}$, Gladys Rueda-Barrios ${ }^{3}$ \\ 1,2,3 Universidad Pontificia Bolivariana, Faculty of Business Administration, Km 7 Vía Piedecuesta, Colombia \\ E-mails:1.juanf.reyes@upb.edu.co; ${ }^{2}$ jairoa.gonzalez@upb.edu.co; ${ }^{3}$ gladys.rueda@upb.edu.co
}

Received 18 March 2020; accepted 25 September 2020; published 30 December 2020

\begin{abstract}
There is little evidence of the role of resources and capabilities related to information systems and technologies (IS/IT) in the adoption of proactive environmental practices in firms. The purpose of this study is to explore the influence of organisational and IS/IT resources and capabilities on the adoption of proactive environmental practices as well as the ultimate effect on environmental performance. By conducting covriance-based structural equation modelling (CB-SEM) to a multi-sample of 129 small, medium and large firms operating in different industrial sectors in Bogotá, Colombia, we found that organisational and IS/IT resources shape the development of capabilities for continuous improvement, stakeholder management, IS/IT support to general functional activities and IS/IT support to environmental management. Further, firm capabilities lead to the adoption of proactive environmental practices, which in turn, determine improvements in environmental performance. Findings support the relevance of IS/IT resources and capabilities in driving proenvironmental behaviour in firms.
\end{abstract}

Keywords: Proactive environmental practices; environmental performance; information systems and technologies (IS/IT); resource-based view of the firm $(\mathrm{RBV})$

Reference to this paper should be made as follows: Reyes-Rodríguez, J.F., González-Bueno, J., Rueda-Barrios, G. 2020. Influence of organisational and information systems and technologies resources and capabilities on the adoption of proactive environmental practices and environmental performance. Enterpreneuship and Sustainability Issues, 8(2), 875-895. http://doi.org/10.9770/jesi.2020.8.2(53)

JEL Classifications: M14, M15

\section{Introduction}

Over the past years, there has been an increasing concern for the social responsibility of firms (Arribas, EspinósVañó, García, \& Oliver, 2019). As part of such social responsibility, particularly, attention has been paid to the preservation of the natural environmental, which demand actions from the business sector by means of rethinking their investments, strategies and operations (García et al., 2019; González-Bueno \& Nuñez Rodríguez, 2018). 


\section{ENTREPRENEURSHIP AND SUSTAINABILITY ISSUES}

ISSN 2345-0282 (online) http://jssidoi.org/jesi/ 2020 Volume 8 Number 2 (December) http://doi.org/10.9770/jesi.2020.8.2(53)

This implies the acquisition and development of organisational attributes strategically used in order to drive response. In this sense, the specific characteristics that influence environmental performance of an individual firm have been a matter of concern in academic studies. That is, the strategic attributes which can be managed consciously by the organisation's leadership in order to achieve superior environmental performance (Etzion, 2007).

Literature subscribed to the Resource-Based View of the firm (RBV, Barney, 1991; Grant, 1991; Wernerfelt, 1984), and the Natural Resource-Based View of the firm (NRBV, Hart, 1995; Hart \& Dowell, 2011) as an extension to the natural environment, has argued for the relevance of valuable and unique resources and capabilities as drivers of corporate response to environmental concerns that have been widely approached empirically (Aragón-Correa et al., 2008; Leonidou et al., 2017; Prieto-Sandoval et al., 2019; Sharma \& Vredenburg, 1998; Torugsa et al., 2012). Such a response is materialised in the form of proactive environmental practices, that ultimately can improve competitive advantage. However, controversies have arisen around such a relationship and thus, it is a topic that remains under study (Arribas, Espinós-Vañó, García, \& Tamošiūnienè, 2019; García et al., 2020). Proactive environmental practices are defined here as organisational actions and decisions concerning the development and introduction of new or improved products, processes, and/or management systems so as to mitigate negative impacts on the natural environment (González-Benito \& González-Benito, 2005; Reyes-Rodríguez et al., 2016).

On the other hand, RBV-related studies show a strategic perspective of information systems and technologies (IS/IT), in which competitive valuable resources and capabilities related to IS/IT are characterised as key contributors to the development of organisational strategies and boost competitive advantages (Bharadwaj, 2000; Bhatt \& Gover, 2005; Mata et al., 1995; Ravinchandran \& Lertwongsatien, 2005; Wade \& Hulland, 2004). Further, a growing number of studies has investigated the relevance of IS/IT in connection with the adoption of proactive environmental practices (Benitez-Amado \& Walczuch, 2012; Ghobakhloo et al., 2018; Hanelt et al., 2017; Seidel et al., 2013). Yet, they have approached predominantly IS/IT as an attribute that contributes in isolation to the implementation of proactive environmental practices rather than as an attribute that jointly operates with other resources and capabilities for such a purpose.

This study subscribes to the RBV framework and attempts to addressing the above mentioned gap in literature by responding whether and how both organisational and IS/IT resources and capabilities influence the adoption of proactive environmental practices and ultimately an improved environmental performance. In doing so, two organisational capabilities: continuous improvement and stakeholder management are explored together with IS/IT capabilities. We hypothesise that such capabilities are proceeded by the existence of organisational and IS/IT resources, and influence the adoption of proactive environmental practices, which in turn improves environmental performance in firms.

Based on data from 129 small, medium and large firms operating in different industrial sectors in Bogotá, Colombia, the paper's contributions are three-fold: (i) an extension of the RBV framework in the context of environmental management by integrating both organisational and IS/IT resources and capabilities; (ii) an enhanced understanding of the role of IS/IT in the pursuit of environmental sustainability in organisations; and (iii) a validation of the research model in a developing country setting.

The following section presents the literature review and hypotheses development. Then, a description of the research methods and design is detailed, followed by the presentation of the study results and analysis. The remaining sections include the discussion of the key findings and an outline of the conclusions of the research. 


\section{Theoretical foundations and research hypotheses}

Literature provides an understanding of proactive environmental practices as a way to boost competitiveness. Under this perspective, the RBV has been considered as a dominant theoretical driving force, arguing that the management of the interface between business and the natural environment comprises the development of organisational capabilities that are built on firm-specific key resources (Chan, 2005; Hart, 1995; Prieto-Sandoval et al., 2019). In the strategic management literature, firm resources are considered as a major antecedent of a strategy (Grant, 1991) and are characterised by their value, non-substitutability, and non-perfect imitability (Barney, 1991).

Firms control resources to take actions for improve efficiency and effectiveness (Barney, 1991). They are categorised as physical, human and organisational and are inputs of production processes (Grant, 1991). Resources differ from capabilities as resources constitute the raw input to support the business activities of the firm, whereas the latter are organisational routines that imply the interaction and complex coordination of the former (Barney, 1991; Grant, 1991). Hence, resources can be viewed as the antecedent of organisational capabilities. In the realm of environmental issues, this suggested relationship holds as experiential, financial and allied resources that are critical for strengthening firm's capabilities associated with the greening of the business (Leonidou et al., 2017).

Under this perspective, we advance in proposing a conceptual model that with the research hypotheses of the study (see Figure 1), which are discussed below.

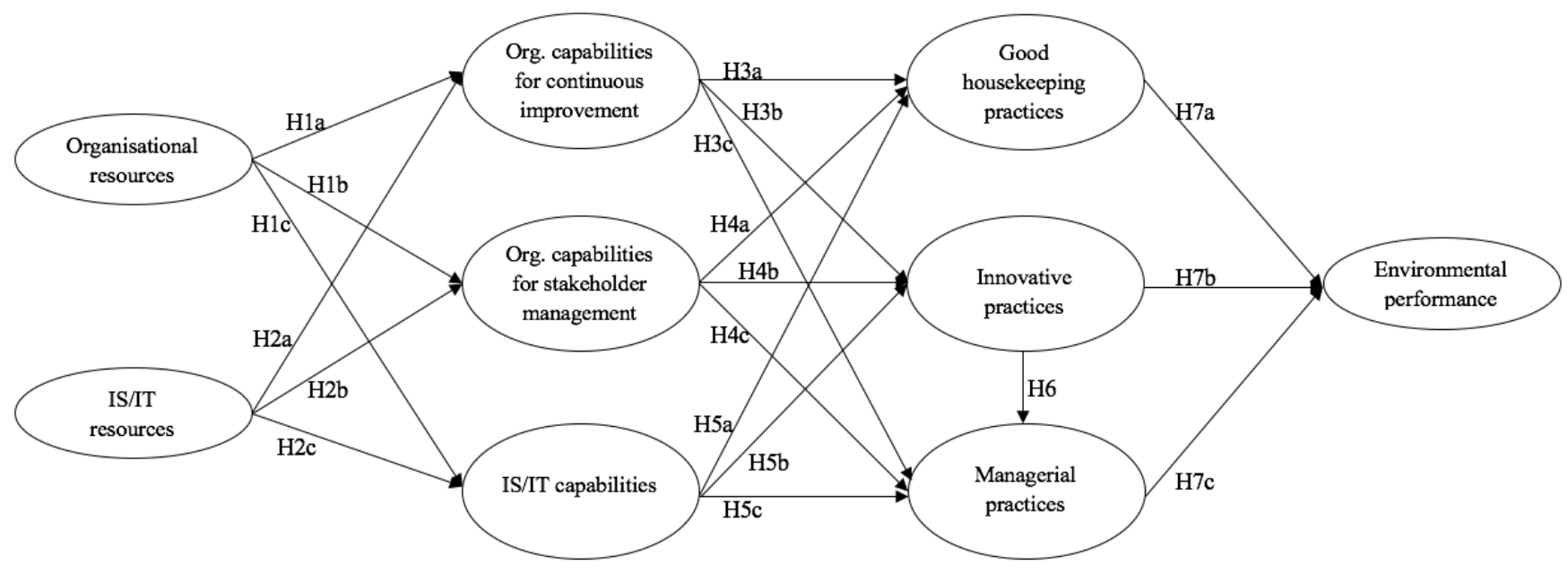

Fig. 1. Conceptual model

Empirical validations in literature on environmental management have approached certain organisational capabilities such as continuous improvement and stakeholder management, which are essential for the adoption of proactive environmental practices (Caldera et al., 2018; Sharma \& Vredenburg, 1998; Torugsa et al., 2012). The former refers to the ability to continuously generate innovations resulting from organisational efforts to reduce, minimise and prevent pollution (Hart, 1995; Sharma \& Vredenburg, 1998). The latter indicates the ability to establish trust-based collaborative relationships with stakeholders in order to achieve environmental goals (Sharma \& Vredenburg, 1998; Torugsa et al., 2012). Developing such organisational capabilities requires holding together heterogeneous and multiple resources across different functions and levels (Leonidou et al., 2017). For instance, physical and technological resources for continuous improvement regarding the redesigning of 


\section{ENTREPRENEURSHIP AND SUSTAINABILITY ISSUES}

ISSN 2345-0282 (online) http://jssidoi.org/jesi/ 2020 Volume 8 Number 2 (December) http://doi.org/10.9770/jesi.2020.8.2(53)

production processes (Chan, 2005; Nuhu, 2016; Russo \& Fouts, 1997). Human resources are also required for the stablishment of a culture that facilitates the innovation (Rueda-Barrios et al., 2018), which entails an effective application of eco-friendly technologies and properly interact with stakeholders to build strong relationships (Chan, 2005; Torugsa et al., 2012).

On the other hand, IS/IT have been regarded as a strategic factor that influence a firm's ability to enhance performance (Ray et al., 2005; Wade \& Hulland, 2004). In this sense, IS/IT capabilities become a relevant construct, referring to an enterprise-wide capability to leverage technology to differentiate from competition that goes beyond a set of sophisticated technological functionalities (Bharadwaj, 2000). They constitute socially complex routines that enable the delivery of information-related services to the organisation and ultimately contribute to competitiveness (Ravinchandran \& Lertwongsatien, 2005). In accordance with the RBV, the complexity of IS/IT implies the firm's ability to mobilise and expand IS/IT -related resources in combination with other resources and capabilities so as to contribute to business value (Bharadwaj, 2000; Ravinchandran \& Lertwongsatien, 2005). Hence, it is expected that a wide variety of organisational resources (e.g., physical, human, organisational, etc.) to be involved for developing such capabilities. We thus formulate the following hypotheses:

Hypothesis 1a: There is a positive effect of organisational resources on the development of organisational capabilities for continuous improvement.

Hypothesis 1b: There is a positive effect of organisational resources on the development of organisational capabilities for stakeholder management.

Hypothesis 1c: There is a positive effect of organisational resources on the development of IS/IT capabilities.

IS/IT resources, considered as assets and capabilities of the company, do not lead to higher performance of the company by themselves. This kind of resources are mediated by organizational capabilities, these capabilities in turn positively affect the performance of the company becoming a source of sustained competitive advantage (Borek et al., 2012; Uwizeyemungu et al., 2018). IS/IT resources serve as a means to complement organisational processes and contributes to creating business value (Pang et al., 2014). Mata et al. (1995) conceptually approach attributes proper of IT, highlighting the managerial IT skills. Similarly, Wade and Hulland (2004) provide a typology of specific IS resources and emphasize resource complementarity in order to study their effect on firm performance. Marhraoui and El Manouar (2020) state that bundles of key IS/IT resources such as IS/IT infrastructure and IS/IT human resources are enablers of more complex or higher-level organisational attributes and therefore, key to the sustainable performance of companies. Likewise, Ridwandono and Subriadi (2019) argue that IS/IT resources are contribute to improve organizational capabilities and therefore the performance of organisations.

Considering continuous improvement and stakeholder management as such higher-level attributes, it is naturally expected that IS/IT resources become essential for the strategic purpose of these capabilities. On the one hand, corporate efforts to continuously improve processes, operations and procedures requires handling, displaying and analysing information, tasks that are performed through the use an infrastructure in IS/IT and the mobilisation of human resources and technical skills in IS/IT. On the other hand, building trust-based relationships with critical stakeholders takes place on the basis of the adequate and fluid exchange of information, which also demands the deployment of these IS/IT-related resources.

As previously mentioned, the notion of IS/IT capabilities points to the ability of a firm to mobilise, implement and expand IS/IT resources in combination with other resources and capabilities (Bharadwaj, 2000; Ravinchandran \& Lertwongsatien, 2005; van de Wetering, 2019). Hence, IS/IT resources are building blocks og IS/IT capabilities. 


\section{ENTREPRENEURSHIP AND SUSTAINABILITY ISSUES}

ISSN 2345-0282 (online) http://jssidoi.org/jesi/ 2020 Volume 8 Number 2 (December) http://doi.org/10.9770/jesi.2020.8.2(53)

Bharadhaw (2000) states that IS/IT capabilities comprise five dimensions: technological infrastructure, human IS/IT talent, knowledge, relationships and architecture. Empirical work has evidenced the influence that resources such as IS/IT human capital, IS/IT infrastructure flexibility, and IS/IT relationship quality directly affects IS/IT capabilities in the functional side (Ravinchandran and Lertwongsatien, 2005). Correa Ospina and Díaz Pinzón (2018) argue that there are relationships among IS/IT resources to build up IS/IT capabilities as enablers on organisational performance. Given the above discussion, the following hypotheses are suggested:

Hypothesis 2a: There is a positive effect of IS/IT resources on the development of organisational capabilities for continuous improvement.

Hypothesis 2b: There is a positive effect of IS/IT resources on the development of organisational capabilities for stakeholder management.

Hypothesis 2c: There is a positive effect of IS/IT resources on the development of IS/IT capabilities.

The abovementioned organisational capabilities for continuous improvement and stakeholder management correspond to the original 'strategic resources' constructs devised by Hart (1995), associated to specific 'strategic environmental capabilities' related to pollution prevention and product stewardship (Aragón-Correa et al., 2008; Caldera et al., 2018; Christmann, 2000; López-Gamero et al., 2009; Sharma \& Vredenburg, 1998). Continuous improvement has been particularly associated to the adoption of pollution prevention in the form of good housekeeping practices as well as innovative practices since they require companies to develop resources such as physical assets, technologies and skills, and cross-functional integration (Russo \& Fouts, 1997) to change the experiential base of organizational activities, routines, and goals (Sharma \& Vredenburg, 1998). Stimuli to waste minimization are also related to "the capacity of organizations to engage in collaborative learning and continuous improvement on a number of fronts" (Vickers \& Cordey-Hayes, 1999, p. 89). Further, continuous improvement capabilities becomes a natural approach when adopting environmental practices related to managerial aspects when working towards the meeting of certifiable international standards (Heras-Saizarbitoria et al., 2020; Prieto-Sandoval et al., 2019). In sum, capabilities for continuous improvement comprises the ability to create new environmental initiatives materialised into products, processes and involves the initiation of changes in environmental policies and activities (Albertini, 2019; Boakye et al., 2020). Thus, the following hypotheses are thus, formulated:

Hypothesis 3a: There is a positive effect of organisational capabilities for continuous improvement on the development of proactive environmental practices related to good housekeeping practices.

Hypothesis 3b: There is a positive effect of organisational capabilities for continuous improvement on the development of proactive environmental practices related to innovative practices practices.

Hypothesis 3c: There is a positive effect of organisational capabilities for continuous improvement on the development of proactive environmental practices related to managemerial practices.

On the other hand, proactive environmental practices in terms of product-stewardship are related to a stronger stakeholder orientation by the inclusion of their perspectives in the processes of product-development and planning (Caldera et al., 2018; Hart, 1995; Torugsa et al., 2012). As previously mentioned, a stakeholder management capability is based on trust-based collaborative relationships with a variety of stakeholders (Sharma \& Vredenburg, 1998; Vishwakarma et al., 2019). Through collaborative relationships with stakeholders, firms can learn more about how firm's operations should be, the improvement of routines and operations, better approaches to product lifecycle assessment and the designing of more environmentally friendly products that meet the expectations of customers and suppliers (Albertini, 2019; Salem et al., 2016). In general, such relationships can 


\section{ENTREPRENEURSHIP AND SUSTAINABILITY ISSUES}

ISSN 2345-0282 (online) http://jssidoi.org/jesi/ 2020 Volume 8 Number 2 (December) http://doi.org/10.9770/jesi.2020.8.2(53)

provide direction and course of action of the strategy and the managerial dimension in which proactive environmental practices are embedded (Albertini, 2019; Buysse \& Verbeke, 2003). Therefore, organisational capabilities for stakeholder management becomes an antecedent of the implementation of proactive environmental practices. The following hypotheses are thus, formulated:

Hypothesis 4a: There is a positive effect of organisational capabilities for stakeholder management on the development of proactive environmental practices related to good housekeeping practices.

Hypothesis 4b: There is a positive effect of organisational capabilities for stakeholder management on the development of proactive environmental practices related to innovative practices.

Hypothesis 4c: There is a positive effect of organisational capabilities for stakeholder management on the development of proactive environmental practices related to managerial practices.

Firm's IS/IT capabilities refer to the ability to mobilise and deploy specific IS/IT resources effectively combined with other resources and capabilities so that superior performance is achieved (Bharadwaj, 2000). They include experience and relational infrastructure (Bhatt \& Gover, 2005), that, when channelled, lead to the adoption of distinctive strategies and the development of competencies (Ravinchandran \& Lertwongsatien, 2005).

IS/IT capabilities imply features for monitoring, analysis, and display of information (e.g., resource consumption, environmentally harmful outputs, etc.) that allows the organisation to make sense of the situation and in turn reconsider beliefs, routines and actions. This provides the ground for the implementation of proactive environmental practices (Seidel et al., 2013). IS/IT capabilities are relevant for storing, managing, and displaying information for the implementation of proactive environmental practices related to managerial aspects (De Camargo Fiorini et al., 2019). For instance, information on human and financial resources as well as audits and periodic evaluations assist in the establishment and dissemination of goals and the benchmarking of activities to improve current practices towards environmental protection (Benitez-Amado \& Walczuch, 2012; De Camargo Fiorini et al., 2019). In the same vein, IS/IT capabilities boost the internal transfer of tacit and explicit knowledge on regulations and best practices in connection with environmental protection between business units and/or functional departments (Benitez-Amado \& Walczuch, 2012; Sharma \& Vredenburg, 1998; Yousif et al., 2017).

At operational level, IS/IT capabilities are key for the exchange of information and knowledge related to lifecycle assessment practices as they require dealing with sorts of information not only from manufacturing-related data but also from suppliers, audits and surveys (Ghobakhloo et al., 2018; Melville, 2010). Market intelligence enabled by IS/IT capabilities may allow firms to sense and seize opportunities in order to respond proactively by the development of environmentally friendly products and services (Benitez-Amado \& Walczuch, 2012). On the other hand, IS/IT capabilities can assist the selection of suppliers based on green criteria and collaborative production management across the supply chain in order to enable environmentally friendly product development (De Camargo Fiorini et al., 2019; Ghobakhloo et al., 2018). Furthermore, the management and control of environmentally-related indicators in production processes (e.g., waste, energy consumption, toxic material, water use, etc.) reduces uncertainties and assists decision making for the improvement of eco-efficiency of the business processes. Less uncertainties about processes help the targeted implementation of technological alternatives with reduced environmental impact (Hanelt et al., 2017). Given the above, we propose the following hypothesis:

Hypothesis 5a: There is a positive effect of IS/IT capabilities on the development of proactive environmental practices related to good housekeeping practices.

Hypothesis 5b: There is a positive effect of IS/IT capabilities on the development of proactive environmental practices related to innovative practices. 


\section{ENTREPRENEURSHIP AND SUSTAINABILITY ISSUES}

ISSN 2345-0282 (online) http://jssidoi.org/jesi/ 2020 Volume 8 Number 2 (December) http://doi.org/10.9770/jesi.2020.8.2(53)

Hypothesis 5c: There is a positive effect of IS/IT capabilities on the development of proactive environmental practices related to managerial practices.

Environmental innovations and practices related to managerial aspects are related. That is, the establishment of management related environmental practices emerges as a result of planned environmental innovations (Rehfeld et al., 2007). The implementation of managerial practices such as environmental management systems is closely linked to pre-existing component of tacit knowledge derived from innovative practices that comprise reformulation and improvement of products, services and processes (Amores-Salvadó et al., 2015; Dragomir, 2020). Such a knowledge becomes a baseline for the formulation of environmental goals and the shaping of policies. Proactive practices in managerial aspects constitute a form of organisational capital (procedures and norms) that guides the greening of the firm provided the technological capital that results from innovative practices in environmental management (Amores-Salvadó et al., 2015; Nemlioglu \& Mallick, 2017). In other words, proactive environmental practices related to tangible innovations in products provides the basis for the adoption of proactive environmental practices related to intangible managerial aspects (Ziegler \& Seijas Nogareda, 2009). Based on this, the following hypothesis is stated:

Hypothesis 6: There is a positive effect of proactive environmental practices related to innovative practices on the adoption of proactive environmental practices related to managerial practices.

Finally, it is of interest to study the effect of proactive environmental practices on firm's environmental performance. Judge and Douglas (1998) refer to environmental performance as the effectiveness of the firm to meet and exceeding social expectations with respect to the natural environment. That is, the ability of the firm to successfully meet and exceed those expectations. Literature has shown a relationship between environmental practices and performance (Chan, 2005), and that those differentiated proactive environmental practices result in dissimilar outcomes on environmental performance (Betts et al., 2018; González-Benito \& González-Benito, 2005; López-Gamero et al., 2009). Therefore:

Hypothesis 7a: There is a positive effect of proactive environmental practices related to good housekeeping practices on environmental performance.

Hypothesis $7 b$ : There is a positive effect of proactive environmental practices related to innovative practices on environmental performance.

Hypothesis 7c: There is a positive effect of proactive environmental practices related to managerial practices on environmental performance.

\section{Methods}

\subsection{Sample and procedures}

We collected data from 129 firms participating in the first and second stages, out of five, of a two-year assistance and education programmes promoted by the Secretary of the Environment of Bogotá, Colombia called Corporate Environmental Management (Gestión Ambiental Empresarial) in 2018. The program intended to engage firms in environmental improvement (see Parker et al., (2009) about this type of programs in general). By addressing these firms, we made sure that they are under the process of acting towards the natural environment by means of the implementation of practices at both operational and managerial levels. In terms of size, the sample consisted of 107 firms performing manufacturing activities in sectors such as paper and printing, chemical, pharmaceutical, metalmechanics, food and beverages, textile, furniture, automotive and oil, wood transformation, and other 


\section{ENTREPRENEURSHIP AND SUSTAINABILITY ISSUES}

ISSN 2345-0282 (online) http://jssidoi.org/jesi/ 2020 Volume 8 Number 2 (December) http://doi.org/10.9770/jesi.2020.8.2(53)

manufacturing activities. The remaining 22 firms operated in service-related sectors such as healthcare, professional and personal services as well as transportation and logistics. In terms of size, according to the classification of the European Commision (Eurostat, 2020), the sample consisted of 49 small firms, employing between 10 and 49 employees; 57 medium-sized firms, employing between 50 and 249 employees; and 23 large firms, employing more than 250 employees.

Prior to the data collection, an early version of the survey instrument was developed by including items from previous studies as well as adaptations based on findings of a qualitative stage prior to this study. Then, a pilot study was performed, which consisted of the application of an initial paper-based questionnaire to 73 firms participating in the programs administered by Bogotá's Secretary of the Environment. Based on the results of validation of the instrument, some adjustments ware made and an on-line version of the questionnaire was then sent to representatives (i.e., general managers, environmental managers, and environmental assistants) of the firms.

After sending the final, on-line questionnaire to a population of 360 firms, 189 questionnaires were returned, which represented $51 \%$ of response rate. Then, procedures to verify the quality of data were carried out since the survey was applied to a pre-recruited non-probabilistic panel (Couper, 2000). We followed the most relevant procedures associated to web-based studies: diversity of respondents, seriousness of responses (i.e., repeatedly endorsing items regardless of content, or acquiescence), and repeated responses (Gosling et al., 2004; Sax et al., 2003). As a result, 22 questionnaires were discarded.

Nonresponse bias (Armstrong \& Overton, 1977) was tested by carrying out wave analysis. Firms who responded right after the survey was made available were compared with those who responded after a first and second reminders. Comparisons of survey results revealed no statistically significant differences between the three groups at the level of demographic variables. Then, 38 further questionnaires were excluded because they came from firms with ten or less employees. Environmental awareness or eco-literacy are low in most micro-enterprise owners since financial and human resources are limited, which limits voluntary action (Mir \& Feitelson, 2007). After following these procedures, the 129 cases were retained in the sample for subsequent analyses.

Data from the final sample were analysed following this sequence: a characterisation of the sample, an exploratory principal component analysis (EPCA), confirmatory factor analysis (CFA), and covariance-based structural equation modelling (CB-SEM).

\subsection{Measures}

Variable selection in environmental management, and in general sustainability-related studies, is critical (Arribas, Espinós-Vañó, García, \& Morales-Bañuelos, 2019). We adapted items from the literature and used Likert scales (see Appendix).

Some constructs of the questionnaire were measured with the 7-point Likert scale and others with the 5-point scale. The scales were implemented according to the nature and intention of the construct. For the constructs that measured the company's attitude (attention, relationship, adoption, and use), scales from 1 to 5 were used: Stakeholder management, IS/IT capabilities and proactive environmental practices. For the constructs that measured the availability of resources and performance evaluation of the company, scales from 1 to 7 were used: organizational resources, IS/IT resources, continuous improvement and environmental performance. We considered to respect the scales originally proposed by the authors and which were validated in their studies, also with the purpose of comparing our results with those of these sources. However, this is not a limitation since the proposed scales are not mixed within the same construct, and therefore there are no differences between the weight of the variances of the same construct. 


\section{ENTREPRENEURSHIP AND SUSTAINABILITY ISSUES}

ISSN 2345-0282 (online) http://jssidoi.org/jesi/ 2020 Volume 8 Number 2 (December) http://doi.org/10.9770/jesi.2020.8.2(53)

The underlying structure among the variables was evaluated through EPCA with varimax rotation and reliability estimates were calculated (Hair et al., 2009). All loadings of items were equal or above to .600 after performing EPCA. Construct measurements are presented as follows:

Organisational resources: Seven items, including several from Chan (2005) assessed the availability of resources in the firm using a seven-point scale ( $1=$ "scarce" to "7 = very abundant"). After the EPCA, six items were retained constituting one single factor.

IS/IT resources: Seven items were adapted from Byrd and Turner (2000) and Ravinchandran and Lertwongsatien (2005) to assess the degree of each respondent's agreement using a seven-point Likert scale, (" $1=$ completely disagree" to " 7 = completely agree"). They formed one single factor after EPCA.

Continuous improvement. Four items drawn from Sharma and Vredenburg (1998) assessed the degree of each respondent's agreement using a seven-point Likert scale, ("1 = completely disagree" to "7 = completely agree"). Three of them were retained and formed one factor after EPCA.

Stakeholder management. Based on the approach of Aragón-Correa et al. (2008), six items assessed separately-in two complementary statements-the attention given by each firm to different types of stakeholders, as well as the influence of each stakeholder has on the firm's environmental management decisions. Measures consisted of a five-point scale (" $1=$ none" to " $5=$ great attention" or " $5=$ very strong influence"). The combined measure results from multiplying the scores assigned to importance and attention. The six items formed one single factor after EPCA.

IS/IT capabilities: Eleven items adopted in part from Ravinchandran and Lertwongsatien (2005) assessed the extent of use of IS/IT to several functions and activities using a five-point scale ( 1 = "none" to " 5 = very much"). After EPCA, only seven items were retained and organised in two factors, labelled as "IS/IT support to general functional activities" and "IS/IT support to environmental management".

Proactive environmental practices. Seventeen items, several drawing from Christmann (2000), Chan (2005), and Aragón-Correa et al. (2008) assess the degree of adoption of proactive environmental practices using a five-point scale (" 1 = we have not considered this issue at all" to " $5=$ we are leaders in this practice in our sector"). After EPCA, ten of these items were retained in three factors-labelled as "Good Housekeeping Practices", "Innovative Practices", and "Managerial Practices".

Environmental performance. Four items adapted from Karagozoglu and Lindell (2000) assess relative environmental performance, compared with competitors', through a seven-point scale (" 1 = we are far behind" to "7 = we have a very large advantage"). After EPCA, three of them formed one factor.

Control variables: The number of employees was used as a measure for firm size. However, in the structural equation modelling the natural logarithm was calculated and considered as a control variable. Further, a dummy variable was also used as a control variable to measure industrial sector in two main categories: $0=$ services and other activities, and $1=$ manufacturing activities.

\section{Results}

After performing EPCA, confirmatory factor analysis (CFA) was used to assess the fit of the hypothesised measurement model to the data. The procedure of treating ordinal variables with five or more categories as 
continuous variables was followed as it does not impose practical impact on the results (Johnson \& Creech, 1983). As the hypotheses for univariate and multivariate normal distribution of the data were rejected, we performed parameter estimation to assess the measurement model using Robust Maximum Likelihood (RML) method using LISREL 8.8 following a covariance-based approach (Jöreskog et al., 2001).

Standardised item-factor loadings retained with CFA are all greater than or equal to .600 (Hair et al., 2009) and the Average Variance Extracted (AVE) was calculated for all of the constructs in order to determine convergent validity (Fornell \& Larcker, 1981). AVE values were above the .500 threshold in most cases with the exception of innovative practices, whose AVE value was .46. However, given the theoretical grounding of this factor and its relevance for the study, we decided not to exclude it from the model. In order to improve model fit and obtain acceptable values for standardised residuals, the items ORR2, ORR5, ITR2, ITR6, STM4 and ITC1 were dropped (see the Appendix). Table 1 shows the means, standard deviations, reliability coefficients, and correlations among the constructs after conducting CFA.

Table 1. Descriptive statistics and correlations among the variables/constructs

\begin{tabular}{|c|c|c|c|c|c|c|c|c|c|c|c|c|c|c|}
\hline Construct/ variable & Mean & s.d. & 1 & 2 & 3 & 4 & 5 & 6 & 7 & 8 & 9 & 10 & 11 & 12 \\
\hline 1. Size (LnEmp) & 4.389 & 1.263 & - & & & & & & & & & & & \\
\hline 2. Sector & .780 & - & $-.255^{* *}$ & - & & & & & & & & & & \\
\hline 4. IS/IT Resources & 4.921 & 1.355 & $.343^{* *}$ & $-.180^{*}$ & $.520^{* *}$ & .860 & & & & & & & & \\
\hline $\begin{array}{l}\text { 5. Continuous } \\
\text { Improvement }\end{array}$ & 5.568 & 1.069 & $.228^{* *}$ & $-.189^{*}$ & $.407^{* *}$ & $.510^{* *}$ & .807 & & & & & & & \\
\hline $\begin{array}{l}\text { 6. Stakeholder } \\
\text { Management }\end{array}$ & 15.661 & 5.038 & .083 & $-.220^{*}$ & $.389^{* *}$ & $.340^{* *}$ & $.313^{* *}$ & .804 & & & & & & \\
\hline $\begin{array}{l}\text { 7. IS/IT Support to } \\
\text { General Functional } \\
\text { Activities }\end{array}$ & 3.620 & .868 & $.200^{*}$ & -.054 & $.326^{* *}$ & $.372^{* *}$ & .086 & $.228^{* *}$ & .867 & & & & & \\
\hline $\begin{array}{l}\text { 8. IS/IT Support to } \\
\text { Environmental } \\
\text { Management }\end{array}$ & 3.543 & .966 & .028 & -.092 & $.218^{*}$ & $.353^{* *}$ & $.210^{*}$ & $.273^{* *}$ & $.541^{* *}$ & .799 & & & & \\
\hline $\begin{array}{l}\text { 1. Innovative } \\
\text { Practices }\end{array}$ & 3.043 & .744 & -.056 & -.138 & $.391^{* *}$ & $.288^{* *}$ & $.248^{* *}$ & $.300^{* *}$ & .171 & $.223^{*}$ & $.411^{* *}$ & .763 & & \\
\hline $\begin{array}{l}\text { 11. Managerial } \\
\text { Practices }\end{array}$ & 2.871 & .900 & $.230^{* * *}$ & $-.250^{* *}$ & $.372^{* *}$ & $.365^{* *}$ & $.323^{* *}$ & $.430^{* *}$ & $.236^{* *}$ & $.270^{* *}$ & $.236^{* *}$ & $.469^{* *}$ & .804 & \\
\hline $\begin{array}{l}\text { 12. Environmental } \\
\text { Performance }\end{array}$ & 4.341 & 1.116 & .054 & $-.258^{* *}$ & $.371^{* *}$ & $.247^{* *}$ & $.358^{* *}$ & $.376^{* *}$ & $.214^{*}$ & $.273^{* *}$ & $.376^{* *}$ & $.413^{* *}$ & $.331^{* *}$ & .868 \\
\hline
\end{tabular}

Correlations are obtained from summated scales. Scale reliabilities (Cronbach's alpha) are on the diagonal in boldface.

$* \mathrm{p}<.05 ; * \mathrm{p}<.01$.

Furthermore, we found that the squared root of respective AVE for each pair of latent variables were always larger than their shared correlation, which evidenced discriminant validity (Fornell \& Larcker, 1981). The appendix contains the item loadings after conducting CFA as well as the AVE for each construct. Fit statistics for the measurement model were adequate $(\chi 2=565.005, \mathrm{df}=482, \mathrm{p}=.119$, RMSEA $=.024, \mathrm{NFI}=.912$, CFI $=$ $.993, \mathrm{IFI}=.993)$. 
The structural model was stablished taking organisational resources, IS/IT resources, size, and sector as the exogenous latent variables. Size and sector were control variables. Endogenous latent variables comprise continuous improvement, stakeholder management, IS/IT support to general functional activities, IS/IT support to environmental management, good housekeeping practices, innovative practices, managerial practices, and environmental performance.

Figure 2 shows the final results of the structural model, where the parameters for the relationships between the constructs are estimated. The hypothesised model provided an adequate fit to the data $(\chi 2=646.859, \mathrm{df}=558, \mathrm{p}=$ $.005, \mathrm{RMSEA}=.035, \mathrm{CFI}=.984$; IFI $=.984)$. Fit indices are acceptable considering the number of observations per group and the number of observed variables. In particular, under these conditions, it is expected to find significant p-values for the Chi-square statistic even with good fit (Hair et al., 2009).

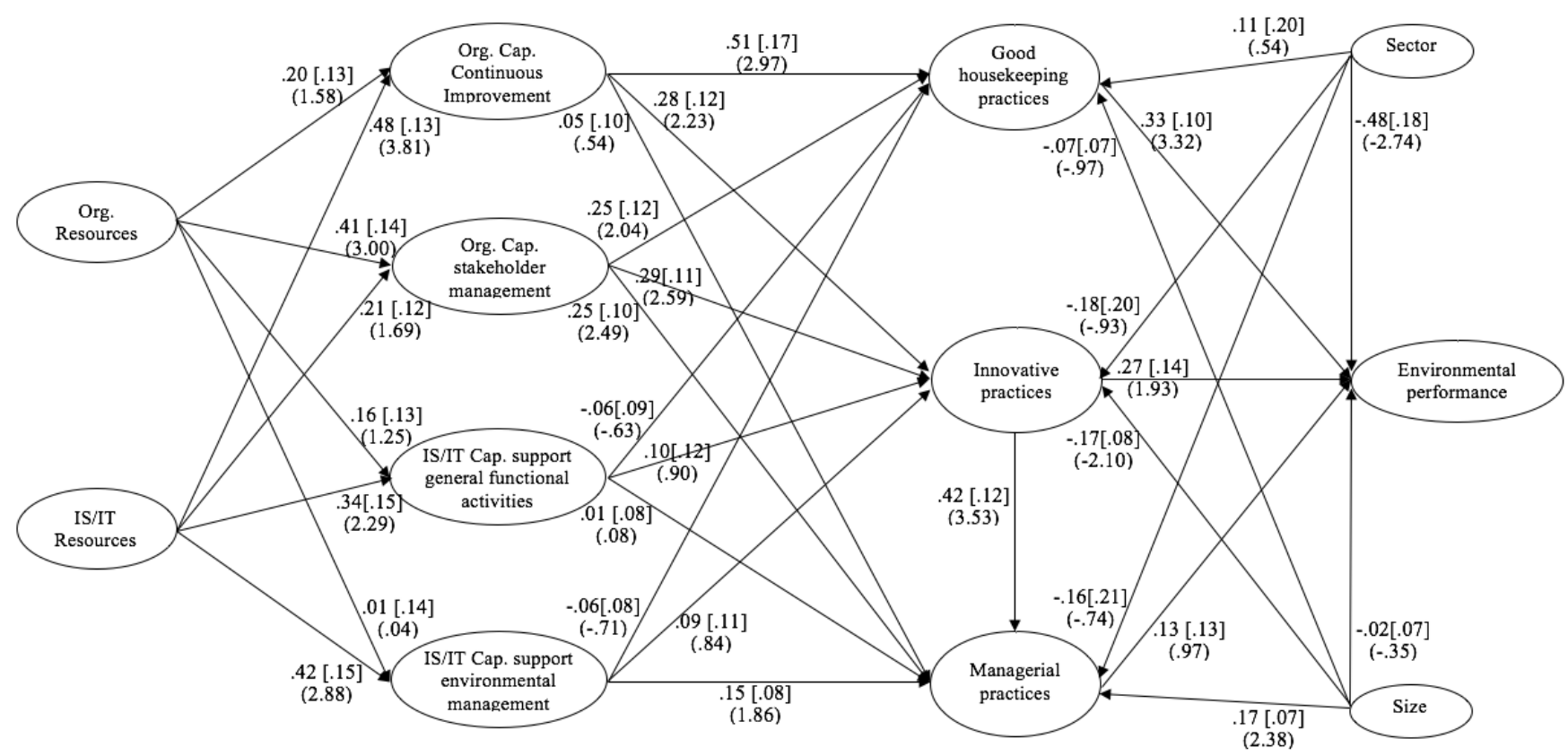

Fig.2. Final results of the structural model $(\chi 2=646.859, \mathrm{df}=558, \mathrm{p}=.005$, RMSEA $=.035, n=129)$. Numbers above are standardised path coefficients [standard errors of estimates], and $t$-values in parenthesis below

According to the results exhibited in figure 2, organisational resources influence only the development of a capability of stakeholder management given the statistically significant effect. Thus, hypothesis 1a is supported whereas hypotheses $1 \mathrm{~b}$ and $1 \mathrm{c}$ are not supported. On the other hand, IS/IT Resources have positive and statistically significant effects on all of the firm capabilities. This provides full support to hypotheses $2 \mathrm{a}, 2 \mathrm{~b}$ and 2c.

Regarding the influence of organisational capabilities for continuous improvement on environmental management practices, only hypotheses $3 \mathrm{a}$ and $3 \mathrm{~b}$ are supported because such capabilities have a statistically significant effect on proactive environmental practices related to both good housekeeping and innovative practices. Yet, hypotheses $4 \mathrm{a}, 4 \mathrm{~b}$, and $4 \mathrm{c}$ are fully supported due to the positive and significant effect of organisational capabilities for stakeholder management on all three forms of proactive environmental practices. Furthermore, because of the 


\section{ENTREPRENEURSHIP AND SUSTAINABILITY ISSUES}

ISSN 2345-0282 (online) http://jssidoi.org/jesi/ 2020 Volume 8 Number 2 (December) http://doi.org/10.9770/jesi.2020.8.2(53)

only statistically effect of IS/IT capabilities related to the support to environmental management on proactive environmental practices related to managerial practices, only hypothesis $5 \mathrm{c}$ is partially supported.

Hypothesis 6 is confirmed due the positive and statistically significant effect of proactive environmental practices related to innovative practices on managerial practices. Concerning the effect of proactive environmental practices on environmental performance, results provided support only to hypotheses $7 \mathrm{a}$ and $7 \mathrm{~b}$ since that performance is influenced only by proactive environmental practices related to good housekeeping and innovative practices. Table 2 sumarises the hypotheses test results of the structural model.

Finally, size has a positive and significant effect on proactive environmental practices related to managerial practices $(\beta=.17 ; p<.05)$, whereas there is a negative and significant influence on innovative practices $(\beta=-.17$; $p<.05)$. Industry sector only has a negative and significant effect on environmental performance $(\beta=-.48 ; p<.01)$.

\section{Discussion}

Results evidenced the strategic role of organisational and IS/IT resources in paving the way to the development of both organisational and IS/IT capabilities. Yet, organisational and IS/IT capabilities are predominantly determined by the availability and use of IS/IT resources rather than organisational resources. In particular, organisational resources are an antecedent of the development of a capability for stakeholder management. That is, sampled firms use their quality control systems, technological and physical resources, and reputation to build trust-based collaborative relationships with stakeholders when dealing with environmental concerns. Despite these results are in line with findings of Chan (2005), we did not find evidence of the effect of organisational resources on continuous improvement and IS/IT capabilities, which partially supports the hypothesised influence of such resources. In this case, firms rely more on the availability, combination and use of IS/IT resources in terms of skills of IS/IT staff, modularity of applications, and technological infrastructure to develop organisational and IS/IT capabilities. Hence, IS/IT resources become a key strategic attribute that determine the development of capabilities as assert Ravinchandran and Lertwongsatien (2005), particularly related to improvement efforts, collaboration with stakeholders and deployment of the IS/IT-related capabilities as such.

Our findings evidence the role of organisational and IS/IT capabilities in boosting the adoption of proactive environmental practices in sampled firms. As the NRBV-related literature predicts (Hart, 1995; Hart \& Dowell, 2011), there is an influence of the capability for continuous improvement on the development of proactive environmental practices at the level of good housekeeping practices and innovative practices (i.e., input substitution, product re-design, and process modification). This shows that continuous improvement is crucial for the adoption of the operational and engineering aspects of proactive environmental practices. That is, such capability in firms drives response through routinely actions in processes and operations that represent incremental changes towards environmental protection. At the same time, it paves the way to more radical changes related to product and process modification based on environmental grounds (Christmann, 2000).

A capability for stakeholder management in the studied firms is linked to the adoption of proactive environmental practices. That is, the importance and attention paid to primary stakeholders (Clarkson, 1995)-owners and shareholders, employees and suppliers-will determine corporate response to environmental concerns through initiatives at operational, technical and managerial levels. This is not surprising as previous literature argues for the importance that managers give to different stakeholder groups to the development of proactive environmental practices given the collaborative relationships that can be established to consider their preferences and garner resources (Aragón-Correa et al., 2008; Buysse \& Verbeke, 2003; Caldera et al., 2018; Sharma \& Vredenburg, 1998). 
ENTREPRENEURSHIP AND SUSTAINABILITY ISSUES

ISSN 2345-0282 (online) http://jssidoi.org/jesi/

2020 Volume 8 Number 2 (December)

http://doi.org/10.9770/jesi.2020.8.2(53)

Table 2. Summary of hypothesis test results

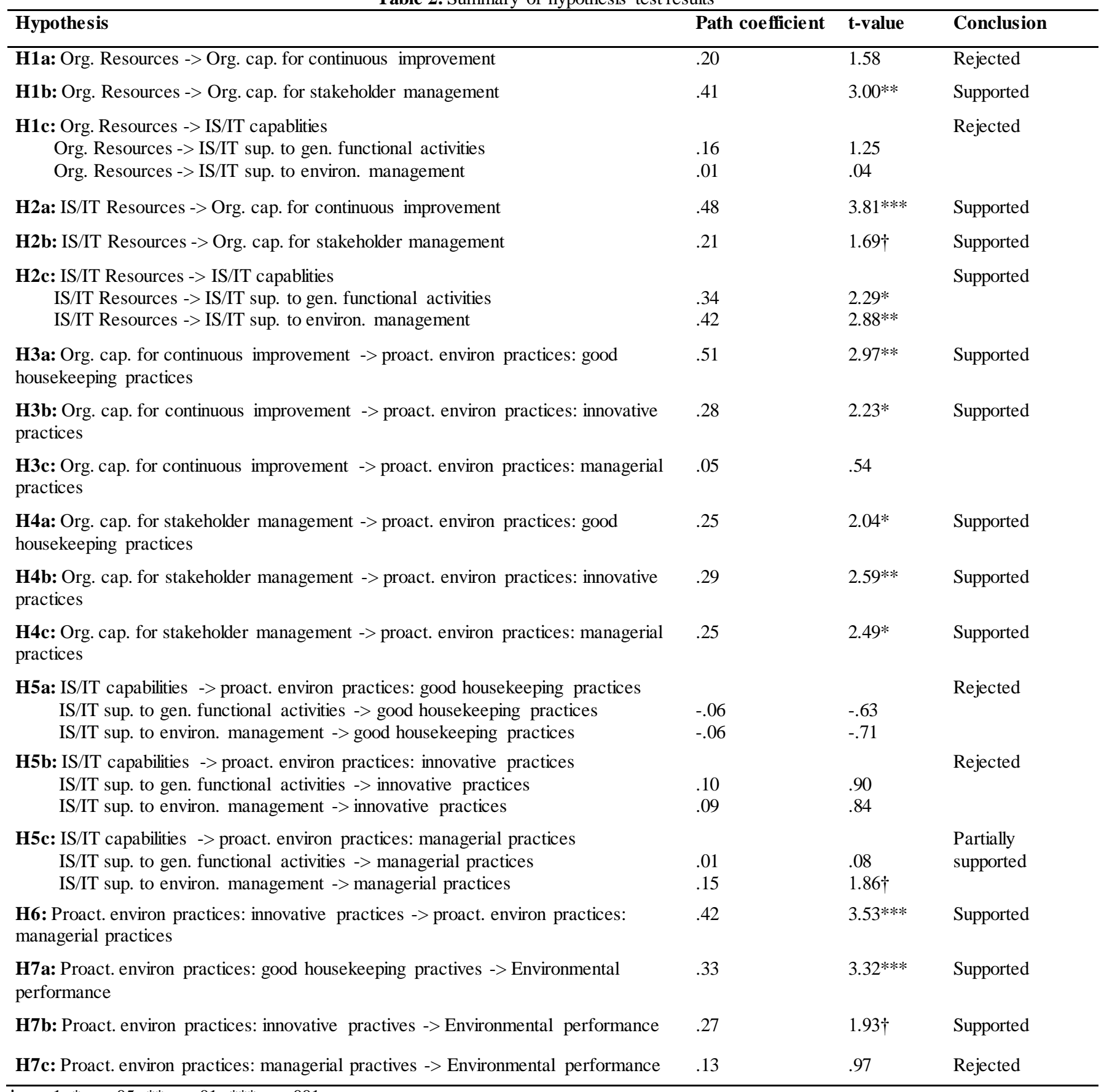

$7 \mathrm{p}<.1 ; * \mathrm{p}<.05 ; * * \mathrm{p}<.01 ; * * * \mathrm{p}<.001$.

Concerning the relationship between IS/IT capabilities and the adoption of proactive environmental practices, there is only evidence of influence of the capability for IS/IT support to environmental management activities on managerial practices. In this sense, results highlight that IS/IT capabilities enable a managerial aspect of environmental protection through capturing, storing, processing and visualising relevant data and information (Ghobakhloo et al., 2018), particularly related to regulations and norms, technical aspects and availability of clean 


\section{ENTREPRENEURSHIP AND SUSTAINABILITY ISSUES}

ISSN 2345-0282 (online) http://jssidoi.org/jesi/ 2020 Volume 8 Number 2 (December) http://doi.org/10.9770/jesi.2020.8.2(53)

technologies. Through these characteristics, capabilities for IS/IT support to environmental management allow the firm to reconsider beliefs, actions, outcomes of operations and routines (Seidel et al., 2013), and redirect them towards the reduction of environmental impact related to prevention and control strategies (Benitez-Amado \& Walczuch, 2012; De Camargo Fiorini et al., 2019; Hanelt et al., 2017).

When looking at both IS/IT resources and capabilities, the findings reveal that IS/IT resources become more critical than IS/IT capabilities when assuming a proactive stance towards environmental protection. In general, continuous improvement and stakeholder management are the main drivers of action in terms of environmental management practices. Notwithstanding, the capabilities approached in this study are mainly shaped by IS/IT resources suggesting thus an indirect effect of IS/IT resources on the adoption of proactive environmental practices. Interestingly, it is worth highlighting the relationship between IS/IT resources and innovative practices, mediated by the development of a continuous improvement capability. For this case, innovative practices, which have higher probability of leading to "complete offsets" (Popp, 2005), ultimately rely on IS/IT resources. The non-supported effects of IS/IT capabilities on proactive environmental practices in terms of good housekeeping and innovative practices may be due to the lack of awareness and knowledge by firms about "the substantial influence of [IS/IT] on the organisation's environmental footprint" and "...how [IS/IT] can be integrated into their environmental programs" (Jenkin et al., 2011, p. 302).

The positive effect of innovative practices on managerial practices found in this study reveals that firms that already achieved environmental innovations have enough capabilities to overcome management barriers (AmoresSalvadó et al., 2015; Ziegler \& Seijas Nogareda, 2009). That is, firms acquire capabilities through the implementation of innovative practices towards environmental protection that allow them to adopt managerial practices such as environmental audits, handbooks of procedures and insurance plans against environmental risks. In other words, innovative approaches in the engineering side of proactive environmental practices (i.e., changes in products and processes) shapes the managerial dimension of those practices in firms.

The role of proactive environmental practices accounts for the relationship between resources and capabilities with environmental performance as previous studies found (Aragón-Correa et al., 2008; Chan, 2005; Leonidou et al., 2017; Russo \& Fouts, 1997; Uwizeyemungu et al., 2018). Firms studied in this work exhibit a better environmental performance derived from innovative practices, which imply transformational changes in processes and business practices. Furthermore, an improved environmental performance is also a consequence of transformations in the operations system (González-Benito \& González-Benito, 2005). We did not find evidence of the implication of the managerial aspects of proactive environmental practices on environmental performance. This is in line with previous studies that indicated that the adoption of managerial practices does not guarantee a contribution to a better environmental performance (Heras-Saizarbitoria et al., 2020) as they may constitute "a form of symbolic environmentalism" (Testa et al., 2018).

In regards to firm size as control variable, results show that smaller firms tend to adopt innovative practices. This may be explained by the flexibility, adaptability, orientation for innovativeness and shorter lines of communication as proper characteristics of small firms that allow environmental proactivity (Aragón-Correa et al., 2008; Boakye et al., 2020; Reyes-Rodríguez et al., 2016), which has been shown in the case of such firms in Colombia (DAMA-CINSET, 1996). However, findings indicate that smaller firms seem to be reluctant for the adoption of managerial practices because they do not perceive standards strategically, and they are specificcustomised whereas standards are generic (Chasse \& Boiral, 2016; Gesternfeld \& Roberts, 2000). In other words, a formalisation does not allow small firms to adopt managerial practices. In the light of the validation of hypothesis 7, these particular findings show that the adoption of managerial practices has innovative practices as an antecedent, but at the same time require formalisation and standards, which is a characteristic of larger firms. 


\section{ENTREPRENEURSHIP AND SUSTAINABILITY ISSUES}

ISSN 2345-0282 (online) http://jssidoi.org/jesi/ 2020 Volume 8 Number 2 (December) http://doi.org/10.9770/jesi.2020.8.2(53)

With respect to industry sector, results show that in the Colombian context, firms belonging to services and other activities exhibit a better environmental performance than manufacturing firms. This supports the conception of manufacturing firms-leather-tanning, non-ferrous metals, wood products, chemical substances, non-metallic products, food, iron and steel, paper and printing -as firms with high environmental significance (DAMACINSET, 1996; Sabogal Mogollón, 2005).

\section{Conclusions, limitations and implications}

The aim of this study was to deepen understand the relationship between both organisational and IS/IT resources and capabilities and proactive environmental practices. Our answer to the research question is that IS/IT resources are more critical than organisational resources in the development of both organisational and IS/IT capabilities. In turn, organisational capabilities such as continuous improvement and stakeholder management are key antecedents of the development of proactive environmental practices related to operational, innovative and managerial aspects whereas IS/IT capabilities adopt a supporting role, specifically towards the adoption of the managerial aspects of proactive environmental practices. The ultimate effect on an improved environmental performance is determined by the more tangible aspects of proactive environmental practices focused on products and processes rather than practices related to managerial aspects.

The paper contributes to the environmental management literature by examining an integration of both organisational and IS/IT resources and capabilities in paving the way to the adoption of proactive environmental practices and improve environmental performance. This constitutes an extension of the RBV framework in the realm of environmental management and confirms the endogenous nature of the greening of businesses. Further, the study contributes to the IS/IT literature by approaching IS/IT understood as resources and capabilities in the pursuit of transformations towards environmental sustainability. The results show that IS/IT does not work in isolation but contributes jointly with further organisational attributes to the fulfilment of organisational goals, in this case the implementation of proactive environmental practices and the improvement of environmental performance. Finally, our study contributes to the literature in environmental management by validating a model that explains environmental commitment in firms in a developing country setting. Despite firms in the sample have been actively participating in training and counselling schemes provided by the environmental authority, our results show that firms in such a particular setting have been able to develop strategic attributes by themselves that allow them to proactively respond to the demands for the protection of the natural environment.

Our research has limitations that must be acknowledged. First, the theoretical model did not explore the implications on competitive advantage so as to fully validate the RBV approach in the context of environmental management. Hence, it is important to explore dimensions of competitive advantage and their relationship with environmental performance and proactive environmental practices. Second, the adopted theoretical approach did not involve external factors that might also explain the adoption of proactive environmental practices. For this purpose, the consideration of contingency and institutional theories could be useful in the exploration of external drivers of proactive environmental practices as well as factors that might moderate the relationship between both organisational and IS/IT capabilities and proactive environmental practices. Third, in terms of methods, the limited sample size did not allow us to provide further analyses by comparing sub-models using industrial sectors as criteria. Finally, the cross-sectional nature of the research design imposed a limitation itself. Longitudinal data will certainly be useful for tracking the development over time of the studied resources and capabilities and the relationships with proactive environmental practices and environmental performance.

The implications for practitioners and policy makers suggests that Colombian firms not only may exhibit differentiated degrees of proactivity in their organisational responses to stakeholder pressures for improved environmental performance, but that they also may be aware of the importance of information management. There 


\section{ENTREPRENEURSHIP AND SUSTAINABILITY ISSUES}

ISSN 2345-0282 (online) http://jssidoi.org/jesi/ 2020 Volume 8 Number 2 (December) http://doi.org/10.9770/jesi.2020.8.2(53)

is a call for the environmental authority in Bogotá to offer training programs and incentives about the importance of information management and their associate mechanisms and technologies. Consequently, resource use, materials and energy could be tracked, and environmental regulations could be monitored. It is necessary to highlight the support of IS/IT in the achievement of environmentally-friendly operations by undertaking substantial changes in products and processes counting with the perceptions and perspectives of different stakeholders.

\section{References}

Albertini, E. (2019). The Contribution of management control systems to environmental capabilities. Journal of Business Ethics, 159(4), 1163-1180. https://doi.org/10.1007/s10551-018-3810-9

Amores-Salvadó, J., Martin-de Castro, G., \& Navas-López, J. E. (2015). The importance of the complementarity between environmental management systems and environmental innovation capabilities: A firm level approach to environmental and business performance benefits. Technological Forecasting and Social Change, 96, 288-297. https://doi.org/10.1016/j.techfore.2015.04.004

Aragón-Correa, J. A., Hurtado-Torres, N., Sharma, S., \& García-Morales, V. J. (2008). Environmental strategy and performance in small firms: A resource-based perspective. Journal of Environmental Management, 86(1), 88-103. https://doi.org/10.1016/j.jenvman.2006.11.022

Armstrong, J. S., \& Overton, T. S. (1977). Estimating nonresponse bias in mail surveys. Journal of Marketing Research, 14(3), 396. https://doi.org/10.2307/3150783

Arribas, I., Espinós-Vañó, M. D., García, F., \& Oliver, J. (2019). Defining socially responsible companies according to retail investors' preferences. Entrepreneurship and Sustainability Issues, 7(2), 1641-1653. https://doi.org/10.9770/jesi.2019.7.2(59)

Arribas, I., Espinós-Vañó, M. D., García, F., \& Tamošiūniené, R. (2019). Negative screening and sustainable portfolio diversification. Entrepreneurship and Sustainability Issues, 6(4), 1566-1586. https://doi.org/10.9770/jesi.2019.6.4(2)

Arribas, I., Espinós-Vañó, M., García, F., \& Morales-Bañuelos, P. (2019). The Inclusion of Socially Irresponsible Companies in Sustainable Stock Indices. Sustainability, 11(7), 2047. https://doi.org/10.3390/su11072047

Barney, J. (1991). Firm resources and sustained competitive advantage. Journal of Management, 17(1), 99-120. https://doi.org/10.1177/014920639101700108

Benitez-Amado, J., \& Walczuch, R. M. (2012). Information technology, the organizational capability of proactive corporate environmental strategy and firm performance: a resource-based analysis. European Journal of Information Systems, 21(6), 664-679. https://doi.org/10.1057/ejis.2012.14

Betts, T. K., Super, J. F., \& North, J. (2018). Exploring the influence of institutional pressures and production capability on the environmental practices - Environmental performance relationship in advanced and developing economies. Journal of Cleaner Production, 187, 1082-1093. https://doi.org/10.1016/j.jcle pro.2018.03.186

Bharadwaj, A. S. (2000). A resource-based perspective on information technology capability and firm performance: An empirical investigation. MIS Quarterly, 24(1), 169. https://doi.org/10.2307/3250983

Bhatt, G. D., \& Gover, V. (2005). Types of information technology capabilities and their role in competitive advantage: An empirical study. Journal of Management Information Systems, 22(2), 253-277. https://doi.org/10.1080/07421222.2005.11045844

Boakye, D. J., TIngbani, I., Ahinful, G., Damoah, I., \& Tauringana, V. (2020). Sustainable environmental practices and financial performance: Evidence from listed small and medium-sized enterprise in the United Kingdom. Business Strategy and the Environment, December 2019, 2583-2602. https://doi.org/10.1002/bse.2522

Borek, A., Helfert, M., Ge, M., \& Parlikad, A. K. (2012). IS/IT Resources and Business Value: Operationalization of an Information Oriented Framework. In R. Zhang, J. Zhang, Z. Zhang, J. Filipe, \& J. Cordeiro (Eds.), Enterprise Information Systems (pp. 420434). Springer Berlin Heidelberg.

Buysse, K., \& Verbeke, A. (2003). Proactive environmental strategies: a stakeholder management perspective. Strategic Management Journal, 24(5), 453-470. https://doi.org/10.1002/smj. 299

Byrd, T. A., \& Turner, D. E. (2000). Measuring the flexibility of information technology infrastructure: Exploratory analysis of a construct. Journal of Management Information Systems, 17(1), 167-208. https://doi.org/10.1080/07421222.2000.11045632

Caldera, H. T. S., Desha, C., \& Dawes, L. (2018). Exploring the characteristics of sustainable business practice in small and medium-sized enterprises: Experiences from the Australian manufacturing industry. Journal of Cleaner Production, 177, 338-349. https://doi.org/10.1016/j.jc lepro.2017.12.265

Chan, R. Y. K. (2005). Does the natural-resource-based view of the firm apply in an emerging economy? A survey of foreign invested enterprises in China. Journal of Management Studies, 42(3), 625-672. https://doi.org/10.1111/j.1467-6486.2005.00511.x

Chasse, S., \& Boiral, O. (2016). Legitimizing corporate (Un)sustainability: A case study of passive SMEs. Organization \& Environment, 1086026616672065. https://doi. org/10.1177/1086026616672065

Christmann, P. (2000). Effects of "best practices" of environmental management on cost advantage: The role of complementary assets. Academy of Management Journal, 43(4), 663-680. https://doi.org/10.5465/1556360 


\section{ENTREPRENEURSHIP AND SUSTAINABILITY ISSUES}

ISSN 2345-0282 (online) http://jssidoi.org/jesi/ 2020 Volume 8 Number 2 (December) http://doi.org/10.9770/jesi.2020.8.2(53)

Clarkson, M. B. E. (1995). A stakeholder framework for analyzing and evaluating corporate social performance. Academy of Management Review, 20(1), 92. https://doi.org/10.2307/258888

Correa Ospina, M. L., \& Díaz Pinzón, B. H. (2018). Capacidad en tecnologías de la información y desempeño organizacional: un estudio en el contexto colombiano. Innovar, 28(69), 99-116. https://doi.org/10.15446/innovar.v28n69.71699

Couper, M. P. (2000). Web surveys: A review of issues and approaches. Public Opinion Quarterly, 64(4), 464-494. https://doi.org/10.1086/318641

DAMA-CINSET. (1996). Valoración del impacto ambiental de la pequeña y mediana industria en el Distrito Capital. CINSET.

De Camargo Fiorini, P., Chiappetta Jabbour, C. J., Lopes de Sousa Jabbour, A. B., Oliveira Stefanelli, N., \& Fernando, Y. (2019). Interplay between information systems and environmental management in ISO 14001-certified companies. Management Decision, 57(8), MD07-2018-0739. https://doi. org/10.1108/MD-07-2018-0739

Dragomir, V. D. (2020). Practical aspects of environmental strategy. In V. D. Dragomir (Ed.), SpringerBriefs in applied sciences and technology (pp. 33-73). Springer. https://doi.org/10.1007/978-3-030-29548-6_2

Etzion, D. (2007). Research on organizations and the natural environment, 1992-present: A review. Journal of Management, 33(4), 637664. https://doi.org/10.1177/0149206307302553

Eurostat. (2020). Small and medium-sized enterprises (SMEs). https://ec.europa.eu/eurostat/web/structural-business-statistics/structuralbusiness-statistics/sme

Fornell, C., \& Larcker, D. F. (1981). Evaluating structural equation models with unobservable variables and measurement error. Journal of Marketing Research, 18(1), 39. https://doi.org/10.2307/3151312

García, F., González-Bueno, J., Guijarro, F., \& Oliver, J. (2020). Forecasting the Environmental, Social, and Governance Rating of Firms by Using Corporate Financial Performance Variables: A Rough Set Approach. Sustainability, 12(8), 1-18. https://doi.org/10.3390/su12083324

García, González-Bueno, Oliver, \& Riley. (2019). Selecting Socially Responsible Portfolios: A Fuzzy Multicriteria Approach. Sustainability, 11(9), 2496. https://doi.org/10.3390/su11092496

Gesternfeld, A., \& Roberts, H. (2000). Size matters: Barriers and prospects for environmental management in small and medium-sized enterprises. In R. Hillary (Ed.), Small and Medium-Sized Enterprises and the Environment: Business imperatives (pp. 106-118). Greenlaf.

Ghobakhloo, M., Azar, A., \& Fathi, M. (2018). Lean-green manufacturing: the enabling role of information technology resource. Kybernetes, 47(9), 1752-1777. https://doi.org/10.1108/K-09-2017-0343

González-Benito, J., \& González-Benito, Ó. (2005). Environmental proactivity and business performance: an empirical analysis. Omega, 33(1), 1-15. https://doi. org/10.1016/j.omega.2004.03.002

González-Bueno, J. A., \& Nuñez Rodríguez, J. (2018). La inversión socialmente responsable: una mirada desde las agencias de rating social de VIGEO-EIRIS Y MSCI ESG STATS. Finance, Markets and Valuation, 4(1), 39-55.

Gosling, S. D., Vazire, S., Srivastava, S., \& John, O. P. (2004). Should we trust web-based studies? A comparative analysis of six preconceptions about internet questionnaires. American Psychologist, 59(2), 93-104. https://doi.org/10.1037/0003-066X.59.2.93

Grant, R. M. (1991). The resource-based theory of competitive advantage: Implications for strategy formulation. California Management Review, 33(3), 114-135. https://doi.org/10.2307/41166664

Hair, J. F., Black, W., Babin, B., \& Anderson, R. (2009). Multivariate data analysis (7th ed.). Pearson.

Hanelt, A., Busse, S., \& Kolbe, L. M. (2017). Driving business transformation toward sustainability: exploring the impact of supporting IS on the performance contribution of eco-innovations. Information Systems Journal, 27(4), 463-502. https://doi.org/10.1111/isj. 12130

Hart, S. L. (1995). A natural-resource-based view of the firm. Academy of Management Review, 20(4), 986-1014. https://doi.org/10.5465/amr.1995.9512280033

Hart, S. L., \& Dowell, G. (2011). Invited editorial: A natural-resource-based view of the firm. Journal of Management, 37(5), 1464-1479. https://doi.org/10.1177/0149206310390219

Heras-Saizarbitoria, I., Boiral, O., García, M., \& Allur, E. (2020). Environmental best practice and performance benchmarks among EMAS-certified organizations: An empirical study. Environmental Impact Assessment Review, 80(May 2019), 106315. https://doi.org/10.1016/j.eiar.2019.106315

Jenkin, T. A., McShane, L., \& Webster, J. (2011). Green information technologies and systems: Employees' perceptions of organizational practices. Business \& Society, 50(2), 266-314. https://doi.org/10.1177/0007650311398640

Johnson, D. R., \& Creech, J. C. (1983). Ordinal measures in multiple indicator models: a simulation study of categorization error. American Sociological Review. https://doi.org/10.2307/2095231

Judge, W. Q., \& Douglas, T. J. (1998). Performance implications of incorporating natural environmental issues into the strategic planning process: An empirical assessment. Journal of Management Studies, 35(2), 241-262. https://doi.org/10.1111/1467-6486.00092

Jöreskog, K. G., Sörbom, D., \& Du Toit, S. H. C. (2001). LISREL 8: New statisticalfeatures. Scientific Software International.

Karagozoglu, N., \& Lindell, M. (2000). Environmental management: Testing the win-win model. Journal of Environmental Planning and Management, 43(6), 817-829. https://doi.org/10.1080/09640560020001700

Leonidou, L. C., Christodoulides, P., Kyrgidou, L. P., \& Palihawadana, D. (2017). Internal drivers and performance consequences of small firm green business strategy: The moderating role of external forces. Journal of Business Ethics, 140(3), 585-606. https://doi.org/10.1007/s10551-015-2670-9

López-Gamero, M. D., Molina-Azorín, J. F., \& Claver-Cortés, E. (2009). The whole relationship between environmental variables and firm performance: Competitive advantage and firm resources as mediator variables. Journal of Environmental Management, 90(10), 


\section{ENTREPRENEURSHIP AND SUSTAINABILITY ISSUES}

ISSN 2345-0282 (online) http://jssidoi.org/jesi/ 2020 Volume 8 Number 2 (December) http://doi.org/10.9770/jesi.2020.8.2(53)

3110-3121. https://doi.org/10.1016/j.jenvman.2009.05.007

Marhraoui, M. A., \& El Manouar, A. (2020). Organizational Agility and the Complementary Enabling Role of IT and Human Resources: Proposition of a New Framework. In Lecture Notes in Information Systems and Organisation (pp. 55-65). https://doi.org/10.1007/978-3-030-34269-2_4

Mata, F. J., Fuerst, W. L., \& Barney, J. B. (1995). Information technology and sustained competitive advantage: A resource-based analysis. MIS Quarterly, 19(4), 487. https://doi.org/10.2307/249630

Melville, N. P. (2010). Information systems innovation for environmental sustainability. MIS Quarterly, $34(1)$, 1. https://doi.org/10.2307/20721412

Mir, D. F., \& Feitelson, E. (2007). Factors affecting environmental behavior in micro-enterprises. International Small Business Journal: Researching Entrepreneurship, 25(4), 383-415. https://doi.org/10.1177/0266242607078583

Nemlioglu, I., \& Mallick, S. K. (2017). Do Managerial Practices Matter in Innovation and Firm Performance Relations? New Evidence from the UK. European Financial Management, 23(5), 1016-1061. https://doi.org/10.1111/eufm.12123

Nuhu, N. A. (2016). The use and effectiveness of management control systems in the Australian public sector. Macquarie University.

Pang, M.-S., Lee, G., \& DeLone, W. H. (2014). IT Resources, Organizational Capabilities, and Value Creation in Public-Sector Organizations: A Public-Value Management Perspective. Journal of Information Technology, 29(3), 187-205. https://doi.org/10.1057/jit.2014.2

Parker, C. M., Redmond, J., \& Simpson, M. (2009). A review of interventions to encourage SMEs to make environmental improvements. Environment and Planning C: Government and Policy, 27(2), 279-301. https://doi.org/10.1068/c0859b

Popp, D. (2005). Uncertain R\&D and the Porter hypothesis. Contributions in Economic Analysis \& Policy, 4(1). https://doi.org/10.2202/1538-0645.1423

Prieto-Sandoval, V., Jaca, C., Santos, J., Baumgartner, R. J., \& Ormazabal, M. (2019). Key strategies, resources, and capabilities for implementing circular economy in industrial small and medium enterprises. Corporate Social Responsibility and Environmental Management, 26(6), 1473-1484. https://doi.org/10.1002/csr.1761

Ravinchandran, T., \& Lertwongsatien, C. (2005). Effect of information systems resources and capabilities on firm performance: A resource-based perspective. Journal of Management Information Systems, 21(4), $237-276$. https://doi.org/10.1080/07421222.2005.11045820

Ray, Muhanna, \& Barney. (2005). Information technology and the performance of the customer service process: A resource-based analysis. MIS Quarterly, 29(4), 625. https://doi.org/10.2307/25148703

Rehfeld, K.-M., Rennings, K., \& Ziegler, A. (2007). Integrated product policy and environmental product innovations: An empirical analysis. Ecological Economics, 61(1), 91-100. https://doi.org/10.1016/j.ecolecon.2006.02.003

Reyes-Rodríguez, J. F., Ulhøi, J. P., \& Madsen, H. (2016). Corporate Environmental Sustainability in Danish SMEs: A Longitudinal Study of Motivators, Initiatives, and Strategic Effects. Corporate Social Responsibility and Environmental Management, 23(4), 193-212. https://doi.org/10.1002/csr.1359

Ridwandono, D., \& Subriadi, A. P. (2019). IT and Organizational Agility: A Critical Literature Review. Procedia Computer Science, 161, 151-159. https://doi.org/10.1016/j.procs.2019.11.110

Rueda-Barrios, G., Gonzalez-Bueno, J., Rodenes Adam, M., \& Moncaleano Rodríguez, G. (2018). La cultura organizacional y su influencia en los resultados de innovación en las pequeñas y medianas empresas. Espacios, 39(42), 36.

Russo, M. V, \& Fouts, P. A. (1997). A resource-based perspective on corporate environmental performance and profitability. Academy of Management Journal, 40(3), 534-559. https://doi.org/10.5465/257052

Sabogal Mogollón, J. H. (2005). Variables que determinan la inversión ambiental en la pequeña y mediana empresa (PyME) de Bogotá: caso AERCAR. Uniandes.

Salem, M. A., Shawtari, F. A., Shamsudin, M. F., \& Hussain, H. I. (2016). The relation between stakeholders' integration and environmental competitiveness. Social Responsibility Journal, 12(4), 755-769. https://doi. org/10.1108/SRJ-12-2015-0189

Sax, L. J., Gilmartin, S. K., \& Bryant, A. N. (2003). Assessing response rates and nonresponse bias in web and paper surveys. Research in Higher Education, 44(4), 409-432. https://doi.org/10.1023/A:1024232915870

Seidel, S., Recker, J., \& vom Brocke, J. (2013). Sensemaking and sustainable practicing: functional affordances of information systems in green transformations. MIS Quarterly,37(4), 1275-1299. https://doi.org/10.25300/MISQ/2013/37.4.13

Sharma, S., \& Vredenburg, H. (1998). Proactive corporate environmental strategy and the development of competitively valuable organizational capabilities. Strategic Management Journal, 19(8), 729-753. https://doi.org/10.1002/(SICI)10970266(199808) 19:8<729::AID-SMJ967>3.0.CO;2-4

Testa, F., Iraldo, F., \& Daddi, T. (2018). The effectiveness of EMAS as a management tool: A key role for the internalization of environmental practices. Organization and Environment,31(1), 48-69. https://doi.org/10.1177/1086026616687609

Torugsa, N. A., O’Donohue, W., \& Hecker, R. (2012). Capabilities, proactive CSR and financial performance in SMEs: Empirical evidence from an Australian manufacturing industry sector. Journal of Business Ethics, 109(4), 483-500. https://doi.org/10.1007/s10551-011-1141-1

Uwizeyemungu, S., Raymond, L., Poba-Nzaou, P., \& St-Pierre, J. (2018). The complementarity of IT and HRM capabilities for competitive performance: a configurational analysis of manufacturing and industrial service SMEs. Enterprise Information Systems, 12(10), 1336-1358. https://doi. org/10.1080/17517575.2018.1448118

van de Wetering, R. (2019). IT Infrastructure Capability and Health Information Exchange: The Moderating Role of Electronic Medical Records' Reach. In W. Abramowicz \& A. Paschke (Eds.), Business Information Systems Workshops (pp. 397-407). Springer 


\section{ENTREPRENEURSHIP AND SUSTAINABILITY ISSUES}

ISSN 2345-0282 (online) http://jssidoi.org/jesi/ 2020 Volume 8 Number 2 (December)

http://doi.org/10.9770/jesi.2020.8.2(53)

International Publishing.

Vickers, I., \& Cordey-Hayes, M. (1999). Cleaner production and organizational learning. Technology Analysis \& Strategic Management, 11(1), 75-94. https://doi.org/10.1080/095373299107591

Vishwakarma, A. K., Nema, A. K., \& Sangle, S. (2019). What determines environmental proactiveness in the Indian cement sector? An empirical study. Journal of Cleaner Production, 234, 961-971. https://doi.org/10.1016/j.jc lepro. 2019.06.291

Wade, \& Hulland. (2004). The resource-based view and information systems research: Review, extension, and suggestions for future research. MIS Quarterly, 28(1), 107. https://doi.org/10.2307/25148626

Wernerfelt, B. (1984). A resource-based view of the firm. Strategic Management Journal, 5(2), 171-180. https://doi.org/10.1002/smj. 4250050207

Yousif, M., Magnusson, J., \& Pessi, K. (2017). IT Agility: Current State, Organizational Contingencies, and Future Research Avenues. Proceedings of the 50th Hawaii International Conference on System Sciences (2017), 5205-5213. https://doi.org/10.24251/hicss.2017.631

Ziegler, A., \& Seijas Nogareda, J. (2009). Environmental management systems and technological environmental innovations: Exploring the causal relationship. Research Policy, 38(5), 885-893. https://doi.org/10.1016/j.respol.2009.01.020

Juan Felipe REYES-RODRIGUEZ holds a $\mathrm{PhD}$ in Management from Aarhus University, Denmark. He is associate professor at the department of Business Administration at Universidad Pontificia Bolivariana, Campus Bucaramanaga, Colombia. His current research interests include corporate sustainability with a particular focus on SMEs, entrepreneurship and sustainable entrepreneurship as well as IS/IT in organisations. His research output has been published in journals such as Corporate Social Responsibility and Environmental Management, and Journal of Global Strategic Management, among others.

ORCID ID: https://orcid.org/0000-0001-6815-0388

Jairo GONZÁLEZ-BUENO received the B.S. degree in financial engineering from the Universidad Autónoma de Bucaramanga, Colombia, in 2004, the M.S. degree in business administration from Universidad Industrial de Santander, Colombia, in 2012, and the Ph.D. in business management and administration from Universitat Politècnica de València, Spain, in 2018. He is currently an associate professor of finance at the faculty of business administration, Universidad Pontificia Bolivariana, Colombia. His current research interests include portfolio management, finance ethics and valuation. His research has been published in Journal of Business Economics and Management; Sustainability; and Journal Finance, Markets and Valuation, among others. He is a member of the Editorial Board of the Journal Economics. Ecology. Socium; and Finance, Markets and Valuation.

ORCID ID: https://orcid.org/0000-0002-5896-094X

Gladys RUEDA-BARRIOS received the B.S. degree in business administration from the Universidad Autónoma de Bucaramanga, Colombia, in 2000, and the $\mathrm{PhD}$ in integration of Information Technologies in organisations from Universidad Politècnica de València, Spain, in 2012. She is currently an associate professor in organisational studies at the faculty of business administration, Universidad Pontificia Bolivariana, Colombia, as well as associate researcher at the Ministry of Science and Technology of Colombia. Her current research interests include organisational culture, IT in organisations, and entrepreneurship.

ORCID ID: https://orcid.org/0000-0002-8344-2722 
ENTREPRENEURSHIP AND SUSTAINABILITY ISSUES

ISSN 2345-0282 (online) http://jssidoi.org/jesi/ 2020 Volume 8 Number 2 (December)

http://doi.org/10.9770/jesi.2020.8.2(53)

Appendix. Cons truct ope rationalisation

Construct/items

Physical resources (e.g. plant, equipment and materials)

Human resources (e. g., well trained and engaged staff)

Organisational resources (e.g. having well-established quality control systems and cash management systems)

Item code

Loading

Technological resources (e.g. unique technologies to produce quality products)

Systems and information technologies

Reputation of the firm

ORR1

.725

ORR2

$-$

ORR3

.815

ORR4

.817

ORR5

$-$

ORR6

.807

IS/IT resources $(A V E=.553)$

The technology infrastructure needed to electronically link our firm with external business partners (i.e., key

customers, suppliers, alliances) is present and in place today.

ITR1

.756

The capacity of our network infrastructure and connection speed adequately meets our current operative business needs.

Our application systems are very modular; that is, business units are supported by a module and/or application to carry out operations

Corporate data is currently sharable across business units and organisational boundaries

ITR2

ITR3

.763

Our IS staff has the ability to quickly learn and apply new technologies as they become available.

ITR4

.716

IT projects are jointly developed by both the IS department and business units

ITR5

.771

We have established long term partnerships with IT vendors and service providers to respond to our IT needs in a timely and effective manner

ITR7

Continuous improvement $(A V E=.597)$

We generate feasible and low cost solutions to our environmental problems

We have carried out activities that are no required by the regulator

We can assess the environmental impact of our activities in order to identify needs and opportunities for

improvement

COI1 $\quad .666$

$\mathrm{COI} 2 \quad .818$

$\mathrm{COI} 3 \quad .824$

Stakeholder management $(A V E=.577)$

Suppliers

STM1 $\quad .738$

Stockholders/owners

STM2 $\quad .713$

Employees

STM3 $\quad .823$

Customers

STM4

IS/IT support to general functional activities $(A V E=.628)$

Providing necessary information to customers

Determining customer requirements (i.e., products, preference, pricing, and quantity)

Reengineering business processes

Integrating the firm with its suppliers

Increasing the speed of logistic activities

$\begin{array}{lc}\text { ITC1 } & - \\ \text { ITC2 } & .755 \\ \text { ITC3 } & .891 \\ \text { ITC4 } & .783 \\ \text { ITC5 } & .731\end{array}$

IS/IT support to environmental management (AVE=.679)

Assessing the environmental impact of our firm's activities

ITC6

.901

Gathering information required for environmental management (e.g., regulations and norms, technical aspects and availability of clean technologies)

ITC7 $\quad .739$

Good Housekeeping Practices (AVE=.517)

All the water taps are always perfectly closed when they are not in use

PEP1

Avoid wasting the chemical products that we use in the production plant

PEP2 
ENTREPRENEURSHIP AND SUSTAINABILITY ISSUES

ISSN 2345-0282 (online) http://jssidoi.org/jesi/ 2020 Volume 8 Number 2 (December)

http://doi.org/10.9770/jesi.2020.8.2(53)

Innovative Practices ( $A V E=.460)$

Modify product design to reduce environmental impact

PEP4 $\quad .649$

Replace polluting raw materials by less polluting materials

PEP5 $\quad .730$

Change production processes to improve environmental performance

$\begin{array}{ll}\text { PEP6 } & .659\end{array}$

Evaluate or select our suppliers including environmental requirements as criteria

PEP7 $\quad .673$

Managerial Practices $(A V E=.583)$

Carry out environmental audits

PEP8 $\quad .684$

Have in place an insurance plan against environmental risks and incidents

PEP9 $\quad .814$

Have in place a handbook of procedures including precise instructions about environmental operations in the

production plant

PEP10 $\quad .786$

Environmental Performance (.700)

Reduction of energy consumption

ENP1 $\quad .758$

$\begin{array}{lll}\text { Become pioneers in carrying out environmental improvement actions } & \text { ENP2 } & .836\end{array}$

Pollution prevention at the source

ENP3

.909

Make your research more visible, join the Twitter account of ENTREPRENEURSHIP AND SUSTAINABILITY ISSUES: @Entrepr69728810

Copyright (C) 2020 by author(s) and VsI Entrepreneurship and Sustainability Center

This work is licensed under the Creative Commons Attribution International License (CC BY).

http://creativecommons.org/licenses/by/4.0/

(c) (1) Open Access 